\title{
Turning points in climate change adaptation
}

\author{
$\underline{\text { Saskia Elisabeth Werners }}^{1}, \underline{\text { Erik van Slobbe }}^{1}, \underline{\text { Tobias Bölscher }}^{2}$, Albert Oost $^{3}$, Stefan Pfenninger $^{4}$, Giacomo Trombi $^{5}$, Marco Bindi $^{5}$ \\ and Marco Moriondo ${ }^{6}$
}

\begin{abstract}
Concerned decision makers increasingly pose questions as to whether current management practices are able to cope with climate change and increased climate variability. This signifies a shift in the framing of climate change from asking what its potential impacts are to asking whether it induces policy failure and unacceptable change. In this paper, we explore the background, feasibility, and consequences of this new framing. We focus on the specific situation in which a social-political threshold of concern is likely to be exceeded as a result of climate change, requiring consideration of alternative strategies. Action is imperative when such a situation is conceivable, and at this point climate change becomes particularly relevant to decision makers. We call this situation an "adaptation turning point." The assessment of adaptation turning points converts uncertainty surrounding the extent of a climate impact into a time range over which it is likely that specific thresholds will be exceeded. This can then be used to take adaptive action. Despite the difficulty in identifying adaptation turning points and the relative newness of the approach, experience so far suggests that the assessment generates a meaningful dialogue between stakeholders and scientists. Discussion revolves around the amount of change that is acceptable; how likely it is that unacceptable, or more favorable, conditions will be reached; and the adaptation pathways that need to be considered under these circumstances. Defining and renegotiating policy objectives under climate change are important topics in the governance of adaptation.
\end{abstract}

Key Words: adaptation turning points; climate change; governance; tools; uncertainty

\section{INTRODUCTION}

One of the biggest challenges is dealing with uncertainties in the future climate, but also in population, economy, and society. This requires a new way of planning, which we call adaptive delta planning. It seeks to maximize flexibility: keeping options open and avoiding "lock-in." In the meantime, we prepare the so-called delta decisions about the measures to take if our current water system reaches its limits.

- Government Commissioner Wim Kuijken at the Deltas in Times of Climate Change conference, ${ }^{[1]} 2010$

The above quotation signifies a new framing of adaptation planning in Dutch water management. In this new framing, the adaptation problem is defined by the tenability of the current water management regime under climate change (Delta Commissioner 2010). With this explicit definition of the adaptation problem, the Delta Programme moves away from the more typical process of adaptation planning, which begins with the generation and interpretation of climate projections, followed by an analysis of their impacts and finally the design and assessment of adaptation options to moderate those impacts (Dessai and Hulme 2004, 2009). The Delta Programme is not alone in this respect. Recent studies note that to satisfy information needs of policy makers, adaptation assessments are transposed by beginning from the adaptation problem in its decision context rather than climate projections (Cash et al. 2006, Pyke et al. 2007, Reeder and Ranger 2011, Downing 2012, Hanger et al. 2013, Werners et al. 2013). This inverted approach to adaptation assessment is an illustration of a solution used by actors to connect climate change to their pre-existing political interests or policy competences, as suggested in the rationale of the Symposium "The Governance of Adaptation," leading up to this Special Feature (http://www.adaptgov.com/the-framing-ofadaptation). In the case of the Delta Programme, assessments ask how much longer current policies and management practices are expected to suffice and when adjustments will be required. This recognizes that climate change will become salient for practitioners if it threatens management objectives or results in conditions that society perceives as unacceptable. It presumes that adaptation becomes relevant only if the amount of change is unacceptable or interests can be realized more effectively through alternative management options. Although this framing of the adaptation challenge is essentially appealing, few concrete examples exist and there is no agreed-on assessment approach.

We explored the background, feasibility, and consequences of framing the adaptation problem in terms of climate changeinduced policy failure and unacceptable change. Examples of studies that use such framing have so far focused on hydrological and technical limits to policy success. They include flood risk and the standards of protection around the Thames Estuary (Reeder and Ranger 2011), and flood safety and water supply in the Netherlands (Kwadijk et al. 2010). We expanded this focus to include cases with policy objectives defined by social-ecological issues.

We built on cases from Europe, primarily from the Europeanfunded FP7 project MEDIATION and the Dutch Delta Programme. Our experience shows that reframing the implications of climate change in terms of the tenability of actors' interests under climate change can stimulate the dialogue between the research and policy community about the amount of change that is acceptable, when conditions might be reached that are unacceptable or more favorable, how likely these conditions are, and which adaptation pathways to consider. The assessment offers opportunities to bridge the science-policy interface for adaptation planning.

${ }^{1}$ Wageningen UR, ${ }^{2}$ Swedish University of Agricultural Sciences, ${ }^{3}$ Deltares, ${ }^{4}$ Imperial College London, ${ }^{5}$ Department of Agri-Food Production and Environmental Sciences (DISPAA), University of Florence, ${ }^{6} \mathrm{CNR}$-IBIMET 


\section{BACKGROUND: GOVERNANCE OF ADAPTATION AND REFRAMING CLIMATE IMPACTS IN TERMS OF THE TENABILITY OF POLICY OBJECTIVES UNDER CLIMATE CHANGE}

In this section, we report on the background of framing adaptation issues in terms of climate change-induced policy failure and unacceptable change. This framing starts from the recognition that climate change becomes relevant to policy makers if it threatens current management objectives or results in conditions that society perceives as undesirable (e.g., O'Brien and Wolf 2010, Dow et al. 2013). If such a situation is conceivable, next to knowing the extent of the threat, at least equally important is to know when and how likely it is that the situation will occur.

Reframing climate impacts in terms of potential policy failure and unacceptable change has the important consequence that it invites discussion on thresholds that society does not wish to transgress. Ultimately, this question is a normative one: How much change and risk is society willing to accept (Steffen 2009)? Many studies of adaptation view the legal and political system as boundary conditions. However, by focusing on those boundaries and how to move them, greater realization of adaptation may be achieved (c.f., Cosens and Williams 2012, Adger et al. 2013). The focus on thresholds highlights that adaptation operates at two distinct levels: changes to the physical environment and changes to the decision environment, including the rules, norms, values, and policy objectives (Howden et al. 2007). Adjusting policy objectives themselves can be considered an adaptation, yet this option is missing in mainstream adaptation guidance and most practice (e.g., UNECE 2009, UKCIP 2010, Clar et al. 2013).

Here we directly touch on the governance of adaptation. An important characteristic is that it facilitates the collaboration and negotiation of learning-by-doing across different levels of government, nongovernmental actors, and individual actors (Folke et al. 2005); in addition, that the rules for allowing change in policy and management have to coevolve with the changing system. A crucial question is "What are the rules for changing the rules?" It is crucial because the time scales of the biophysicalsystem responses and the social- and legal-system responses can be significantly mismatched, obstructing timely changes in management (Walker 2012). Thus, setting and changing the rules and norms, i.e., social-political thresholds, are important aspects of the governance of adaptation.

Practical examples of the assessment of the tenability of policy under climate change exist. Kwadijk et al. (2010) introduced the concept of "adaptation tipping points" for a policy study of longterm water safety in the Netherlands. These are points where the magnitude of change due to climate change or sea level rise is such that the current management strategy will no longer be able to meet its objectives. The concept has proved successful in assessing and communicating water-related risks, and it has become one of the scientific concepts underpinning the Dutch long-term water strategy (Haasnoot et al. 2013). A similar planning approach was developed and tested for flood risk in the Thames estuary (Lavery and Donovan 2005, Stafford Smith et al. 2011).

We recognize that thresholds and tipping points have recently garnered much attention in understanding the dynamics of climate impacts (Dow et al. 2013, Lenton and Ciscar 2013). This trend is critically reviewed by, among others, Russill and Nyssa (2009). To avoid confusion with the term "tipping point" that people tend to associate with major change in biophysical systems (Folke 2006), we use the term "adaptation turning point" for the specific situation in which a social-political threshold of concern is likely to be exceeded because of climate change. A socialpolitical threshold can be defined by a formal policy objective or norm as well as informal societal preferences, stakes, and interests. We appreciate that in the case of formal policy objectives, the assessment of adaptation turning points will be relatively uncontested and may converge on a moment in time at which existing policies and management practices may fail because of climate change. Examples are the Delta Programme (Delta Commissioner 2010) and the Thames Estuary 2100 project (Reeder and Ranger 2011). Focusing on societal preferences, values, and interest (e.g., Adger et al. 2009, van Asselt and Renn 2011, Dow et al. 2013), the assessment of turning points will be more diffuse and therefore likely not to render a well-defined moment in time.

Figure 1 depicts the important aspects of an adaptation turning point. Figure 1a illustrates that the existence of an adaptation turning point does not mean that management is impossible and that catastrophic consequences are to be faced. Rather it does imply progressive failure of the current management practices (a rocky road), such that actors may wish to turn to alternative strategies (unexplored land). That said, we recognize that for actors to adapt and take the 'benign fork' off the rocky road is not a simple task (Abel et al. 2011, Geels 2011, Renaud et al. 2013). Figure 1b illustrates how scenario uncertainty can be translated into a time range in which an adaptation turning point is likely to occur. Communicating uncertainty as a time range when a critical threshold will be reached is a crucial aspect of the assessment and a notable diversion from expressing uncertainty by an impact range in a certain projection year. The assessment also delimits the time available to adapt (Haasnoot et al. 2013). Importantly, reaching a turning point can be, but not necessarily is, because of a biophysical tipping point.

\section{METHOD AND CASE STUDY RESULTS}

In this section, we offer three practical cases of assessing the implication of climate change in terms of climate change-induced policy failure and unacceptable change. Building on previous studies (Kwadijk et al. 2010, Reeder and Ranger 2011, Werners et al. 2013), we discuss for each case the following questions:

- What defines unacceptable change: What social-political thresholds exist for each actor?

- Under which climatic conditions are thresholds reached?

- Can adaptation turning points be identified and, if so, when are these reached?

Cases were selected on the basis of the following criteria. (1) The case represented a social-ecological system, with both socialpolitical and natural science aspects. (2) The case was a concern of multiple actors and reflected a complex governance context. (3) The case fitted the MEDIATION research project. Case study selection in MEDIATION was done first with the aim of acquiring the largest possible variation of adaptation challenges 
Fig. 1. Illustration of an adaptation turning point. (1a) The current direction is becoming unattractive in time (the rocky road) and a turn to alternative routes may be considered (the unexplored land). (1b) A threshold (here: failing safety standards at a sea level rise of $0.2 \mathrm{~m}$ relative to 1990) is translated into a time range in which the threshold is likely to be reached. The figure uses projected global-averaged, sea-level rise for the 21st century from the Intergovernmental Panel on Climate Change (IPCC) assessment report (IPCC 2001). The dark shading is the model average envelope for all IPCC Special Report on Emissions Scenarios (SRES) greenhouse gas scenarios; the light shading is the envelope for all models and all SRES scenarios; and the outer lines include an allowance for an additional land-ice uncertainty (Church et al. 2008).

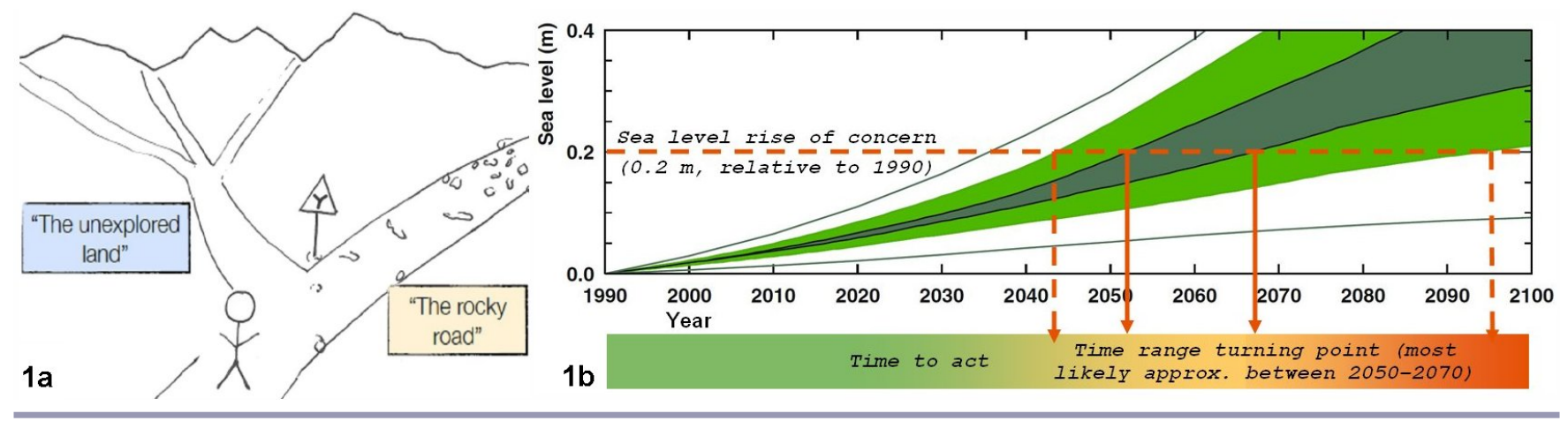

at different scales in Europe and second on the pragmatic basis that data availability and experience allowed for completion of the case within the project lifetime.

Table 1 provides an overview of the methods used to assess adaptation turning points in the three selected cases. No agreedon and unified approach exists to assess climate change-induced policy failure or adaptation turning points. We present three attempts at such an assessment to discuss the feasibility and consequences of framing adaptation problems in terms of climate change-induced policy failure and unacceptable change. The method selection in the case studies was guided by the data and tools available and necessary to perform the desired assessment. This resulted in the use of different methods and tools in each case. For example, in the first case, suitable scenario projections were available; in the second case, there was no suitable impact model, but data were available to allow a statistical regression approach; and in the third case, we reverted to integrating expert opinion and scarce literature references. The selection of tools had a bearing on the assessment, which is in line with our objective to discuss the feasibility and consequences of an assessment of adaptation turning points.

A more detailed analysis of method selection can be found in van Slobbe et al. (2014) and Werners et al. (2015). This analysis was the basis for developing a structured methodology to choose research methods for specific adaptation questions (Hinkel and Bisaro 2014). The methodology offers a series of decision trees and criteria that lead from the framing of adaptation questions to possible research methods. It has helped to rationalize the method selection and can inspire researchers in finding suitable methods and tools for a specific adaptation question.

\section{Turning points for salmon restoration programs, Rhine river basin}

\section{Social-political thresholds of interest}

This case study investigated whether climate change could render the policy to reintroduce Atlantic salmon (Salmo salar) into the River Rhine untenable (Bölscher et al. 2013). The case offers an adaptation turning point assessment for nature conservation policies. Atlantic salmon was a common anadromous fish species in the Rhine that became extinct in the 1950s. Reintroduction began when the Rhine state governments accepted the Rhine Action Plan in 1987 (ICPR 2009). The Rhine national governments, the regional authorities, and nongovernmental organizations are involved in the implementation effort. Bringing back the salmon is therefore not only an abstract water policy objective, but also an inspiration for many small-scale public and private initiatives along the Rhine streams and rivers (Buijse et al. 2002).

In 2001 the Rhine ministers adopted Rhine 2020-Programme on the Sustainable Development of the Rhine (ICPR 2001), which resulted in an action plan: Rhine Salmon 2020 (ICPR 2004). The main objective is the re-establishment of a self-sustaining, wild Atlantic salmon population in the Rhine by 2020. As such, it contributes to policy efforts to enable fish migration in the Rhine river basin and improve habitat conditions. In total, investments of $€ 528$ million for the adaptation of infrastructure, i.e., weirs and dams, and habitat restoration were planned up to 2015. These programs do not consider climate change; however, actors are concerned about potential implications for policy success.

\section{Climatic conditions for reaching thresholds}

The most direct link between climate change and the success of the reintroduction program is through water temperature, which affects the propagation and spawning migration of the salmon (Bölscher et al. 2013). In theory, water discharge also influences migration; however, in larger rivers like the Rhine, it is not physically limiting (Todd et al. 2010).

Literature reports diverse thermal boundary conditions for Atlantic salmon (for an overview, see Table 2 in Bölscher et al. 2013). Two boundary conditions have been identified from literature and expert interviews as being particularly threatening to the reintroduction of the salmon: (1) short but regularly occurring periods with potentially lethal temperatures between $25^{\circ} \mathrm{C}$ and $33^{\circ} \mathrm{C}$ and (2) long periods with mean water temperatures 
Table 1. Methods used in case study to assess adaptation turning points.

\begin{tabular}{|c|c|c|c|}
\hline $\begin{array}{l}\text { Case study } \\
\text { Assessment task } \\
\end{array}$ & $\begin{array}{l}\text { Salmon restoration program, Rhine } \\
\text { River }\end{array}$ & Wine production in Tuscany, Italy & $\begin{array}{l}\text { Flood safety and nature } \\
\text { conservation, Wadden Sea, } \\
\text { Netherlands }\end{array}$ \\
\hline $\begin{array}{l}\text { Identify social-political } \\
\text { thresholds }\end{array}$ & $\begin{array}{l}\text { Review of policy documents on salmon } \\
\text { restoration policies and interviews with } \\
\text { salmon experts }\end{array}$ & $\begin{array}{l}\text { Stakeholder interviews (farmers and } \\
\text { cooperatives) }+ \text { two workshops }\end{array}$ & Review of policy documents \\
\hline $\begin{array}{l}\text { Identify climatic conditions for } \\
\text { reaching thresholds }\end{array}$ & $\begin{array}{l}\text { Literature review to identify threshold } \\
\text { values, transient model simulation of } \\
\text { water temperatures (Bölscher et al. } \\
\text { 2013, van Slobbe et al. 2014) }\end{array}$ & $\begin{array}{l}\text { Literature review and statistical } \\
\text { regression model of wine quality } \\
\text { variables (Moriondo et al. 2011) }\end{array}$ & $\begin{array}{l}\text { Literature review and expert } \\
\text { consultation on sediment } \\
\text { behavior, sea level and storm } \\
\text { surge dynamics in relation to } \\
\text { coastal defence (Werners et al. } \\
\text { 2015) }\end{array}$ \\
\hline $\begin{array}{l}\text { Identify when turning points are } \\
\text { reached }\end{array}$ & $\begin{array}{l}\text { Analysis of multitransient scenario } \\
\text { model runs in combination with } \\
\text { literature review on temperature } \\
\text { sensitivity. }\end{array}$ & $\begin{array}{l}\text { Future projection of wine quality at } \\
\text { different altitudes from a statistical } \\
\text { regression model }\end{array}$ & $\begin{array}{l}\text { Risk assessments based on experts } \\
\text { opinion and harmonisation of } \\
\text { existing literature }\end{array}$ \\
\hline $\begin{array}{l}\text { Interpretation and integration } \\
\text { of results }\end{array}$ & $\begin{array}{l}\text { Identification of the turning point and } \\
\text { its uncertainty range. Figure } 2 \text { presents } \\
\text { six different transient model projections } \\
\text { of water temperatures up to } 2100 \text { (three } \\
\text { general circulation models, each forced } \\
\text { by two SRES scenarios) }\end{array}$ & $\begin{array}{l}\text { Identification of the turning point } \\
\text { for moving vineyards to a higher } \\
\text { elevation. Figure } 3 \text { presents the } \\
\text { average of four model simulations up } \\
\text { to } 2100 \text { for one SRES scenario. The } \\
\text { figure distinguishes seven altitude } \\
\text { classes }\end{array}$ & $\begin{array}{l}\text { Identification of a turning point } \\
\text { for the Wadden Sea. Figure } 4 \\
\text { combines a qualitative expert } \\
\text { opinion on sea wall failure and } \\
\text { mudflat loss with values of four } \\
\text { regional climate scenario }\end{array}$ \\
\hline
\end{tabular}

higher than $23^{\circ} \mathrm{C}$, in which case the time window for salmon to migrate from the sea into the Rhine may become too small.

Bölscher et al. (2013) conclude that a water temperature of $23^{\circ} \mathrm{C}$ is a meaningful threshold value for the success of the reintroduction program. However, the dependency of the migration on the duration and timing of such a period of high water temperature is largely unknown. Thus, the tenability of policy success can only be approximated. In effect, the likelihood of an adaptation turning point occurring increases with the number of days that the water temperature is above $23^{\circ} \mathrm{C}$.

\section{Adaptation turning points and lessons}

To identify turning points associated with exposure to periods with mean water temperature above $23^{\circ} \mathrm{C}$, model results were used from van Vliet et al. (2013). Figure 2 shows a distinct increase in this number of days at Lobith, where the Rhine enters the Netherlands from Germany. The figure illustrates the adaptation turning point, assuming that the reintroduction of salmon becomes problematic at a doubling of the number of days with temperature above $23^{\circ} \mathrm{C}$ from the current 20 days to 40 days. The timing of a turning point for salmon policy remains uncertain because, for example, of climate variability, local water temperature differences, and the adaptive capacity of Atlantic salmon. These uncertainties can direct future research.

We observed that the adaptation turning point is projected to fall beyond the horizon of the current action plan Salmon 2020. Although Salmon 2020 is presented as a plan for the 21 st century, this raises the question of the extent to which actors would want to act on the turning point assessment. Further lessons emerge from the discussion of potential adaptation options.

At the European and national scales, temperature standards for cooling water discharge that ought to safeguard the ecological status of the river have already been defined. The extent to which these standards will be successful, however, is questionable; in practice, they prove to be the result of negotiations in which socialeconomic considerations rather than ecological thresholds take precedent. Furthermore, administrators can increasingly make reasoned deviations during implementation. For example, discharge limitations can paradoxically be waived during extreme weather events by appealing to the uniqueness of the situation.

Another notable adaptation option identified by stakeholders is to change the objective. In this case, the reintroduction of the salmon might be rejected in favor of another species that could be used as an indicator for ecological improvements, for example, the European sturgeon (Acipenser sturio). In the end, policy success or failure depends on the effort of a range of organizations operating at different scales in the Rhine river basin.

\section{Turning points in wine production in Tuscany, Italy}

Social-political thresholds of interest

This case study explores whether climate change will make wine production drop below critical levels in Tuscany, Italy. The growth of vines in the region is progressively changing from mixed farming systems to specialized viticulture. Part of this change is the rediscovery and improvement of traditional and native vines, and a switch to quality production with lower yields, fewer chemicals, and increased value of wine produced. The number of vine-growing farms has been reduced by half over the last 20 years, although the average farm size has increased. Significantly, more than half of the total regional vineyard surface is labeled as Designation of Origin. ${ }^{[2]}$

The associations and unions in the region offer incentives in support of quality improvement. Associations also create awareness that agriculture has created a unique landscape in Tuscany that is both productive and internationally recognized for its beauty. The image of the vineyard, surrounded by the 
Fig. 2. Adaptation turning point for the reintroduction of salmon. The figure shows number of days with daily water temperatures exceeding $23^{\circ} \mathrm{C}$ at Lobith for 1980-2099 (15 year average). Thin lines show individual results for three climate models (CNCM3, ECHAM, and IPSL model), colored polygons show the range in results across the models, and thick line shows the average result from the models for the Special Report on Emissions A2 and B1 climate change scenario (2000-2099; data source: van Vliet et al. 2013).

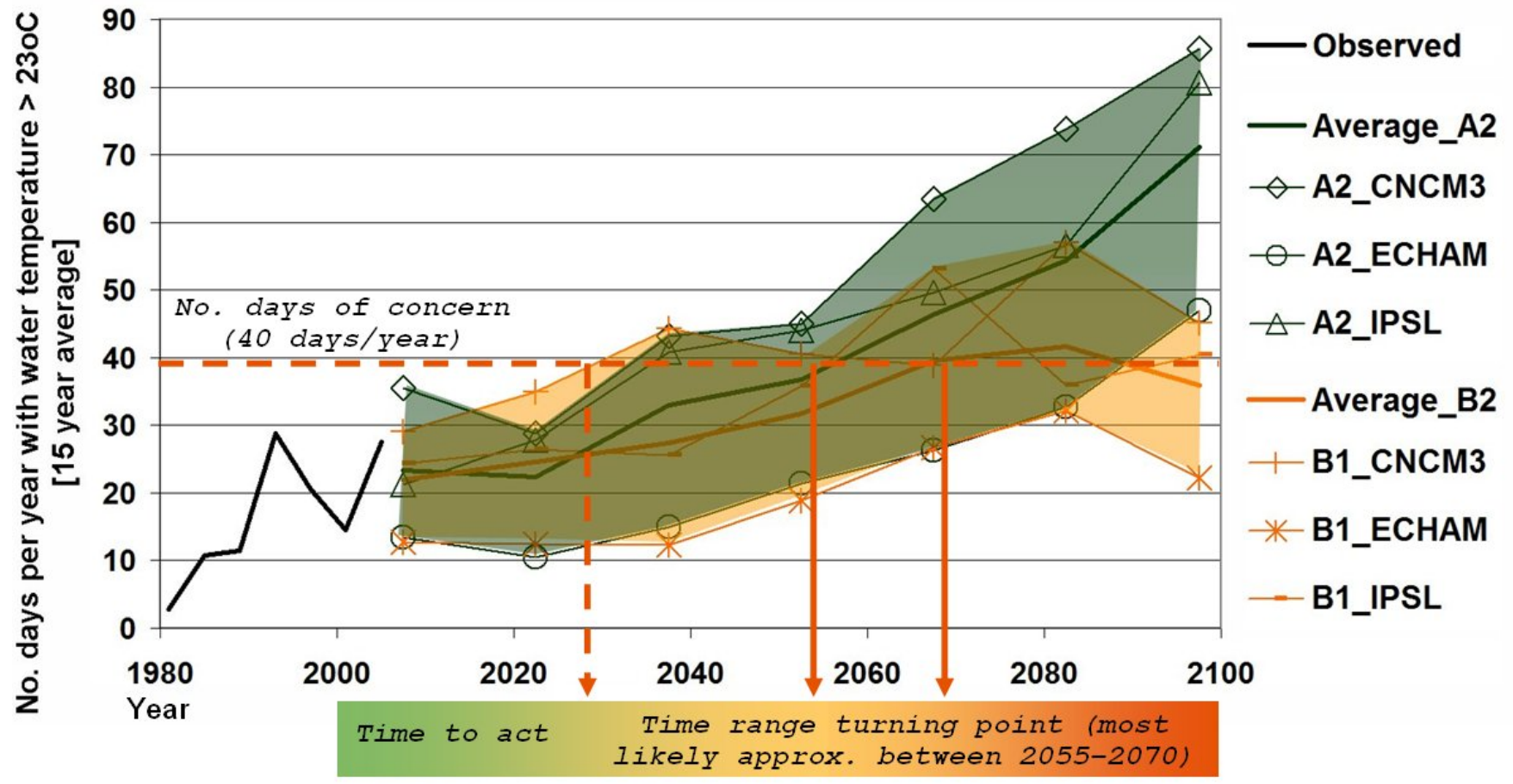

classic, quiet, and clean Tuscan landscape, offers a competitive advantage for the wine produced there (Trombi et al. 2010). Thus, agriculture has both an economic and an environmentallandscape value in Tuscany. These strict landscape conservation and production rules can, however, limit adaptation.

Farmers in Tuscany already notice the consequences of climate change and express an increasing interest in adaptation. The main question is whether wine production in its current form will become unviable in the region, and if so, when. Related questions are whether climate change will make farmers change grape varieties, move to other locations, or switch to other livelihoods. These questions arise in a context where it is feared that changes in viniculture could have detrimental effects on the landscape and therefore on tourism and quality of living. Farmers and government representatives stress the crucial importance of assessing wine quality, rather than the more typically modeled production quantity, because the survival of Tuscan viticulture is strictly linked to its high-quality wines (Werners et al. 2012).

\section{Climatic conditions for reaching thresholds}

Farmers report a strong relationship between an increase in temperature and the reduction of the vegetative cycle of the vine. The grapes are ripening earlier than they were 20 years ago, with a consequent advance of harvest operations. Literature finds there is an initial improvement of wine quality with rising temperature, which then declines beyond a certain threshold, depending on the variety. This corresponds with a shift in the area best suitable for grapevine cultivation either to higher elevations or to higher latitudes (Moriondo et al. 2013).

During stakeholder consultation, farmers indicated that wine production becomes unviable the moment that wine quality drops below a particular level. To assess whether and when this may happen, we used a modeling framework for investigating climate change impacts on viticulture in the Tuscan region (Moriondo et al. 2011). Downscaled climate data (temperature, precipitation, and $\mathrm{CO}_{2}$ level from observations and the Intergovernmental Panel on Climate Change Special Report on Emissions Scenarios scenarios A2 and B2 from different climate models) were input into a vintage quality model for climate change impact assessment. The vintage quality model uses a multiregressive approach and vintage ratings obtained from the most recently published Sotheby's vintage ratings (Stevenson 2005). Vintage ratings are based on a collection of estimates, using six classes, from excellent to disastrous, and a quality score that range from 0 to 100 , with higher values indicating higher quality. Ratings in this case represent a general regionwide average score. Wines are typically rated by single judges or a panel, which attempt to qualify the vintage to-vintage nuances of flavor, aroma, and color and the wine's balance of alcohol and acidity that together best represent that variety's wine style. The ratings are on a scale from 0 to 100 , with the general categories of 0-39 disastrous, 40-59 very bad, 60-69 disappointing, 70-79 average to good, 80-89 good to very good, and 90-100 excellent to superb. 
Fig. 3. Adaptation turning point for Chianti production in Tuscany. The figure shows quality scores in different elevation classes (average of the climate models DMI-HIRHAM, ETHZ-CLM, MPI-M-REMO, and SMHIRCA) for Special Report on Emissions Scenarios scenario A2.



\section{Adaptation turning points and lessons}

Figure 3 shows that in the coming century the quality of vine grown at higher altitudes is likely to surpass that at lower altitudes; best-quality grapevine production areas are projected to gradually move upward. For the coming two decades, the entire area between 200 and $500 \mathrm{~m}$ above sea level is projected to be viable for best-quality wine production rated above 85 . Beyond 2045 , grapevines in the lower altitude classes progressively move out of the desired quality range of 85 , while grapevines above 500 $\mathrm{m}$ show an excellent quality score. Because quality depends on altitude, the timing of an adaptation turning point will differ among farmers depending on the location of their vineyards.

Figure 3 can also be used to identify turning points for the move of viniculture to higher altitudes. For the altitude class of $300 \mathrm{~m}$, the figure shows that at around 2040 it becomes attractive to move $100 \mathrm{~m}$ upward. Higher altitudes become progressively more attractive. Beyond 2060, quality at $300 \mathrm{~m}$ may drop below the desired quality score of 85 , accentuating the need for adaptation. The figure shows that the turning point for moving to a higher altitude lies roughly 10-20 years ahead of the production quality threshold. This is relevant in adaptation, because stocks will need at least 4-10 years to produce at the desired quality. Figure 3 can be used to navigate these different thresholds.

The Tuscan analysis shows that turning points in vine cultivation may well occur in the second half of this century, depending on the location of the vineyards. Around the same time that current production may start to become unviable, the production at higher elevation becomes more attractive, opening up an avenue of adaptive action. Such an adaptive pathway will not be taken lightly, and the decision will have to be studied in the light of many factors, including the existence of other options to adapt. Changing management practices can reduce the risk and postpone the adaptation turning point. There is, however, no guarantee that turning points can be ultimately avoided.

Turning points in flood safety and nature conservation, Wadden Sea region, the Netherlands

Social-political thresholds of interest

This assessment of turning points is carried out on flood safety and nature conservation in the Dutch Wadden region. The Wadden Sea is one of the world's largest tidal areas of its type, consisting of mudflats bordered by barrier islands in the North and the coast of the mainland in the South. It has been on the Unesco World Heritage List since 2009. The assessment focuses on water management in the Wadden region, as addressed in the Dutch Delta Programme. The central goal of the Delta Programme in the Wadden region is to warrant long-term flood safety with special attention to adaptation strategies based on natural processes that can strengthen social-ecological resilience (Delta Commissioner 2010). 
Fig. 4. Adaptation turning point for the Wadden Sea. (a) Probability that the primary sea walls will fail to meet the norms because of a combination of sea level rise and additional storm surge (left). (b) Probability of unacceptable loss of mudflats because of sea level rise, with green indicating low probability and red indicating high probability (right).



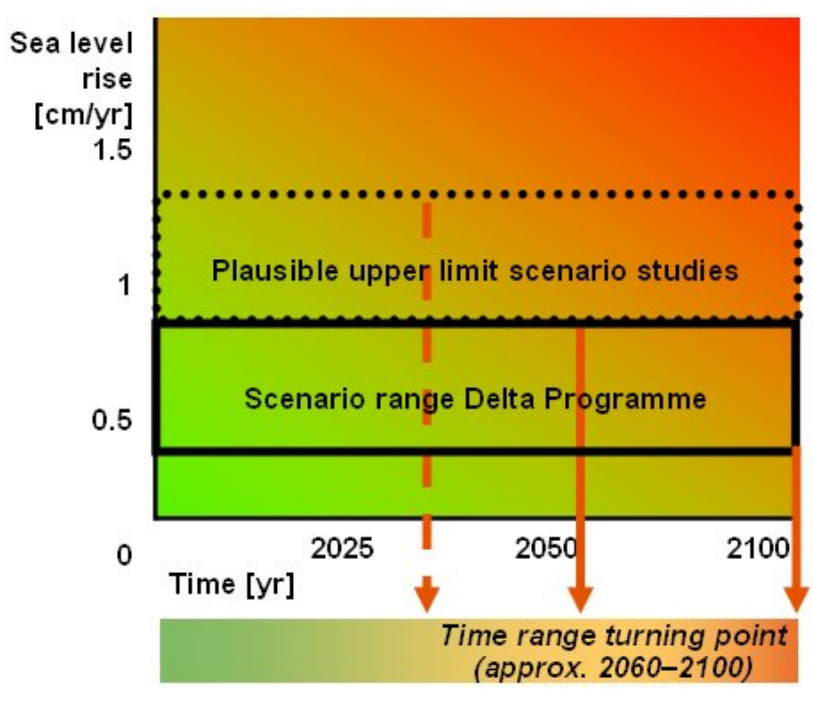

We identified social-political thresholds recognized in the policy documents prepared for the Wadden region Delta Programme and the underlying policies. For safety and nature conservation, the Delta Programme relies heavily on the norms set out in existing policy (Delta Commissioner 2010, van Bijsterveldt et al. 2012). These can be summarized as follows:

- Safety: Safety standards are defined by an extreme water level that flood defenses have to withstand. Depending on the location, this water level corresponds with the $1 / 200$, $1 / 4000$, or $1 / 10,000$ year event. In addition, the amount of sand in the coastal system between inner dune edge and 20 $\mathrm{m}$ below Amsterdam Ordnance Datum needs to be conserved.

- Nature: Norms are derived from national and European regulations. e.g., the Water Framework Directive, Natura 2000, and the European Bird- and Habitat Directive. These particularly include conservation of the area of tidal mudflats and salt marshes.

\section{Climatic conditions for reaching thresholds}

Climate change adds a pressure to coastal ecosystems that are already heavily modified by human interventions. A key question is whether natural sedimentation will keep up with sea level rise or whether the tidal marshes will disappear, significantly changing the character of the Wadden Sea (Oost et al. 2009, van Dobben and Slim 2012). To compensate for sea level rise, more sediment is needed in the Wadden Sea (Kabat et al. 2009, Oost et al. 2009). This is expected to result in erosion of the islands and additional requests for sand replenishment (Delta Commissioner 2010). Increased erosion and channel formation can undermine sea walls and failure of safety norms.

\section{Adaptation turning points and lessons}

Figure 4a illustrates how the probability that the primary sea walls will fail to meet the norms depends on a combination of sea level rise and an increase in storm surge. The figure also indicates the range of values that sea level rise and an increase in storm surge may have, using the scenarios of the Delta Programme for sea level rise (Bruggeman et al. 2011) and the paper by Weisse et al. (2012) for storm surge. The plausible upper limit, indicated in the figure, results from a support study commissioned ahead of the Delta Programme (Vellinga et al. 2009). The figure shows that changes in wave height can cause primary sea walls to fail to meet the norms before sea level rise is projected to do so. However, details of changes in wind climate in the Wadden Sea and its influence on waves and surge levels are as yet unclear (Kabat et al. 2009). It may be noted that wave height is not provided by the Royal Netherlands Meteorological Institute as a scenario parameter because of the large uncertainty in the projections. It is also excluded from the new scenarios developed for the Delta Programme. This signifies that the focus in the program is on the "known unknowns." The assessment also illustrates the importance of assessing turning points with respect to a complexity of factors.

Figure $4 \mathrm{~b}$ illustrates the probability of the loss of mudflats because of sea level rise. It is based on literature review and expert opinion because no comprehensive study currently exists of the overall sediment budget and transport (Oost et al. 2010). Along the coast, in the dunes, and on the island coast, enough sand is available for the next 20-30 years to sustain the mudflats. Even under the most severe climate change scenario, the drowning of mudflats is not expected to start before 2035 and become measurable before 2050. The process of drowning is then expected to take up to a century, turning the Wadden Sea into a lagoon in the long run. Uncertainties remain large. 
It has been a conscious decision for the Delta Programme to prioritize safety issues, yet this makes the integral evaluation of adaptation strategies more difficult and may overlook opportunities for the buy-in of actors beyond those already involved in water management. During conversations in the region, stakeholders were found to differ in how they assess success or failure of policy. National goals can be disconnected from local preferences. For example, inhabitants report they feel insecure when secondary sea walls in the vicinity of settlements fall below eye level. Such safety aspects are currently not recognized in national policy making. Likewise, actors have no shared view on what makes up the "natural quality" of the Wadden region that is to be conserved.

Beause actors differ on what is acceptable change, the adaptation turning point remains ambiguous. Given the large uncertainty in the timing and extent of potential adaptation turning points in the region, experiments and monitoring are considered highly appropriate to adequately respond to changes in the future (Delta Commissioner 2013). Thus, in this case the assessment points to building of resilience rather than predict-and-provide (c.f., Downing 2012).

\section{DISCUSSION}

\section{Social-political thresholds of interest}

Policy goals are not always clearly defined, especially with respect to potential impacts of climate change on ecosystems. Turning points for engineered systems, e.g., dykes, dams, and gates, are relatively well defined by norms and standards. Definition of such norms and targets for natural or social systems seems more complicated and less common in policy.

However, a focus on social-political thresholds of interest helps to identify stakeholders, policy plans, and the spatial and temporal boundaries of the assessment. Beginning the assessment from an existing policy process helps engage actors and provides an easy-to-explain starting point for framing the assessment. A comprehensive analysis of climate change impacts and possible adaptation turning points may need this policy process to be seen in a wider perspective, incorporating the exploration of the various ways stakeholders frame the issues to be addressed. A valuable focus for future work would be full exploration of how the decision context, including the rules, norms, values, and mental models inherited from the past, can constrain adaptation and how this defines turning points.

\section{Climatic conditions for reaching thresholds}

Climate scenarios and impacts are relatively well documented for the three cases. This allows different approaches to be used in the assessment, such as a more qualitative approach (Wadden case) or a quantitative scenario approach (Rhine and Tuscany cases). However, from the perspective of policy goals and stakeholder preferences, we found that some critical scenario parameters were not included in the scenarios developed for adaptation policy planning. In the Wadden case, for example, storm intensity was not included because the uncertainties were considered to be too large to justify projection. An additional complication is that the important assessment of the timing of adaptation turning points is often not possible. This is because climate projections are only provided for one or two future time slices rather than as a function of time. Moreover, detailed knowledge linking social-political thresholds and social-ecological system behavior under changed climate conditions is often lacking, making it difficult to assess turning points even where climate data are available.

\section{Adaptation turning points}

The occurrence of turning points often depends on a mixture of scales and factors. A statement concerning whether or not an adaptation turning point will be reached will always have to clearly indicate the set of policy objectives and societal preferences to which it refers. For social-ecological systems, it may be more difficult to formulate thresholds than for technical systems. Thresholds that have been included in a policy, e.g., water temperature ranges, may ultimately not be indicative of ecological success (or failure, e.g., for the re-establishment of the salmon). The more indirectly the stakeholder preferences are related to climate change, the more difficult it is to determine the adaptation turning points. For example, in the case of the salmon, additional uncertainties are introduced with the adaptability of the species, e.g., adjusting to higher temperatures or finding cooler water refuges. In addition, assessment of adaptation turning points may better communicate the implications of climate change in cases for which quantified policy standards exist than in those for which policy objectives are qualitative. From this perspective, an assessment for water safety may be more successful in yielding communicable results than in improving ecological status.

At the same time, exposing existing uncertainties and ambiguities can be a benefit because they may well forecast resistance encountered when trying to plan adaptation. They may indicate that experimenting, monitoring, and investing in "general resilience" (Walker et al. 2009) are an appropriate and feasible response, or that there is perhaps no consent for a planned response. The latter may also be the case if policy failure is projected to fall beyond the planning horizon of actors.

By expressing uncertainty as a time range, the adaptation turning point concept allows adaptation options to be nested in a time frame. This is particularly useful when developing adaptation options with a longer decision period and implementation lifetime (c.f., Stafford Smith et al. 2011). The concept can also be used to assess thresholds in taking adaptive action, e.g., the Tuscany case. It is important, however, to note that an adaptation turning point can be avoided through a change in policy objectives and socialpolitical preferences. For example, in the Wadden and Rhine cases, this is achieved through reformulating policy norms, e.g., lowering safety standards, or societal objectives, e.g., embracing the sturgeon instead of the salmon as an icon for ecological quality and focus of restoration programs. Table 2 lists strengths and weaknesses of the adaptation turning point assessments derived from the cases.

\section{CONCLUSION}

We observed a move from framing climate change adaptation in terms of impact and vulnerability to a focus on the adaptation decision process and adaptive management (c.f., Downing 2012). To satisfy information needs of policy makers, adaptation assessments are being reversed to begin with the adaptation problem in its decision context rather than climate projections (c. f., Reeder and Ranger 2011). Current management practices are increasingly being assessed in terms of their ability to cope with climate change and increased climate variability. Our goal was to 
improve our understanding of the governance of adaptation by focusing on the specific situation in which, because of climate change, current management practices will no longer be able to meet their objectives. We call this situation an adaptation turning point.

Table 2. Strengths and weaknesses of the adaptation turning point assessments.

\begin{tabular}{|c|c|}
\hline Strength / opportunity & Weakness / Threat \\
\hline $\begin{array}{l}\text { Appropriate to synthesize } \\
\text { available information for the } \\
\text { prioritization of research and } \\
\text { adaptation planning. }\end{array}$ & $\begin{array}{l}\text { Focuses on existing management } \\
\text { objectives. Unknown impacts and } \\
\text { new challenges may be overlooked. }\end{array}$ \\
\hline $\begin{array}{l}\text { More policy-oriented and } \\
\text { stakeholder motivated than } \\
\text { typical impact and vulnerability } \\
\text { assessments. Actors define stakes } \\
\text { to be considered in the } \\
\text { assessment. }\end{array}$ & $\begin{array}{l}\text { Complexity increases with multiple } \\
\text { drivers or in a situation where } \\
\text { there is an indirect link with } \\
\text { climate change. At present only } \\
\text { relatively simple thresholds have } \\
\text { been identified that have sufficient } \\
\text { certainty for adaptation planning. }\end{array}$ \\
\hline $\begin{array}{l}\text { Encourages discussion with } \\
\text { society about (un)acceptable } \\
\text { change and definition of critical } \\
\text { indicator values. Flexible in } \\
\text { considering a range of social- } \\
\text { economic objectives. }\end{array}$ & $\begin{array}{l}\text { Requires identification of social- } \\
\text { political thresholds that are often } \\
\text { ill-defined and/or that need to be } \\
\text { defined jointly with stakeholders }\end{array}$ \\
\hline $\begin{array}{l}\text { Uses scenarios to delineate } \\
\text { uncertainties rather than predict } \\
\text { the future. Expresses } \\
\text { uncertainties in time (when will a } \\
\text { critical point be reached). }\end{array}$ & $\begin{array}{l}\text { Loss of simplicity of } \\
\text { communication for less-well } \\
\text { defined thresholds and turning } \\
\text { points with multiple drivers. }\end{array}$ \\
\hline
\end{tabular}

Because of the novelty of this approach, both for the researchers and the stakeholders, it has proved difficult to conclusively identify adaptation turning points. This is especially true when stakeholder values conflict, or the relationship between policy objectives and climate change is ambiguous. However, the assessment clearly resonates with stakeholders, and new questions that are salient for adaptation planning have surfaced. We feel that the assessment of adaptation turning points complements impact-driven adaptation assessment. More work will be needed to test our observations, particularly with respect to the value of an adaptation turning point assessment in communication with stakeholders and in its implications for the science-policy interface.

In summary, the assessment of adaptation turning points identifies whether and when climate change induces policy failure and unacceptable change. The assessment helps initiate a dialogue between the research and policy communities about why people care, how much stress a system can absorb before an unacceptable situation is reached, when this is likely to happen, and what can be done. Thus, this approach also offers new directions for adaptation assessments and decision support in the governance of adaptation. Adjusting policy objectives themselves can be considered an adaptation, although this option is absent from mainstream adaptation guidance and most practice. A key conclusion is that the governance of adaptation has an important role to play in redefining and renegotiating nonclimate policy objectives under climate change.
${ }^{[1]}$ Conference held in the World Trade Center in Rotterdam, the Netherlands, Wednesday 29 September 2010 (http://www. deltacommissaris.nl/english/news/presentations/thedeltaprogrammeinthenetherlandsthedeltaworksofthefuture.aspx).

${ }^{[2]}$ In Tuscany there are several Designation of Origin (DOs), such as Chianti, Brunello di Montalcino, and Pomino. A total of 39 wines are currently labeled as DOs: 5 are labeled as Controlled Designation of Origin Guaranteed (Denominazione di Origine Controllata e Garantita, DOCG), whereas 34 are labeled only as Controlled Designation of Origin (Denominazione di Origine Controllata, DOC).

Responses to this article can be read online at: http://www.ecologyandsociety.org/issues/responses. $\mathrm{php} / 7403$

\section{Acknowledgments:}

Work on this paper has been kindly supported by a grant from the European Commission through the research project MEDIATION and from the Dutch Ministry of Economic Affairs. A forthcoming special issue in the Journal of Water and Climate Change will present more results on the topic. We are grateful for the valuable comments and insights of Hans Visser, Maarten van der Vlist, and three anonymous reviewers.

\section{LITERATURE CITED}

Abel, N., R. Gorddard, B. Harman, A. Leitch, J. Langridge, A. Ryan, and S. Heyenga. 2011. Sea level rise, coastal development and planned retreat: analytical framework, governance principles and an Australian case study. Environmental Science \& Policy 14 (3):279-288. http://dx.doi.org/10.1016/i.envsci.2010.12.002

Adger, W. N., S. Dessai, M. Goulden, M. Hulme, I. Lorenzoni, D. R. Nelson, L. Naess, J. Wolf, and A. Wreford. 2009. Are there social limits to adaptation to climate change? Climatic Change 93 (3):335-354. http://dx.doi.org/10.1007/s10584-008-9520-Z

Adger, W. N., T. Quinn, I. Lorenzoni, C. Murphy, and J. Sweeney. 2013. Changing social contracts in climate-change adaptation. Nature Climate Change 3(4):330-333. http://dx.doi.org/10.1038/ nclimate1751

Bölscher, T., E. van Slobbe, M. T. H. van Vliet, and S. E. Werners. 2013. Adaptation turning points in river restoration? The Rhine salmon case. Sustainability 5(6):2288-2304. http://dx.doi. org/10.3390/su5062288

Bruggeman, W., M. Haasnoot, S. Hommes, A. te Linde, R. van der Brugge, B. Rijken, E. Dammers, and G. J. van den Born. 2011. Deltascenario's. Verkenning van mogelijke fysieke en sociaaleconomische ontwikkelingen in de 21ste eeuw op basis van KNMI'06 en WLOscenario's, voor gebruik in het Deltaprogramma 2011-2012. 1205747-000. Deltares, Delft, Netherlands.

Buijse, A. D., H. Coops, M. Staras, L. H. Jans, G. J. Van Geest, R. E. Grift, B. W. Ibelings, W. Oosterberg, and F. C. J. M. Roozen. 2002. Restoration strategies for river floodplains along large lowland rivers in Europe. Freshwater Biology 47(4):889-907. http://dx.doi.org/10.1046/i.1365-2427.2002.00915.x 
Cash, D. W., J. C. Borck, and A. G. Patt. 2006. Countering the loading-dock approach to linking science and decision making. Science, Technology, \& Human Values 31(4):465-494. http://dx. doi.org/10.1177/0162243906287547

Church, J. A., N. J. White, T. Aarup, W. S. Wilson, P. L. Woodworth, C. M. Domingues, J. R. Hunter, and K. Lambeck. 2008. Understanding global sea levels: past, present and future. Sustainability Science 3(1):9-22. http://dx.doi.org/10.1007/ s11625-008-0042-4

Clar, C., A. Prutsch, and R. Steurer. 2013. Barriers and guidelines for public policies on climate change adaptation: a missed opportunity of scientific knowledge-brokerage. Natural Resources Forum 37(1):1-18. http://dx.doi.org/10.1111/1477-8947.12013

Cosens, B. A., and M. K. Williams. 2012. Resilience and water governance: adaptive governance in the Columbia River Basin. Ecology and Society 17(4): 3. http://dx.doi.org/10.5751/ ES-04986-170403

Delta Commissioner. 2010. The 2011 Delta Programme. Working on the delta; investing in a safe and attractive Netherlands, now and in the future [English version]. Ministry of Transport Public Works and Water Management, Ministry of Agriculture Nature and Food Quality, Ministry of Housing Spatial Planning and the Environment, Dutch National Government, The Hague, Netherlands.

Delta Commissioner. 2013. Delta Programme 2014. Working on the Delta. Promising solutions for tasking and ambitions. Ministry of Infrastructure and the Environment and Ministry of Economic Affairs, Dutch National Government, The Hague, Netherlands.

Dessai, S., and M. Hulme. 2004. Does climate adaptation policy need probabilities? Climate Policy 4(2004):107-128. http://dx.doi. org/10.1080/14693062.2004.9685515

Dessai, S., M. Hulme, R. Lempert, and R. Pielke, Jr. 2009. Climate prediction: a limit to adaptation? Pages 64-78 in W. N. Adger, I. Lorenzoni, and K. L. O'Brien, editors. Adapting to climate change: thresholds, values, governance. Cambridge University Press, Cambridge, UK.

Dow, K., F. Berkhout, B. L. Preston, R. J. T. Klein, G. Midgley, and M. R. Shaw. 2013. Limits to adaptation. Nature Climate Change 3(4):305-307. http://dx.doi.org/10.1038/nclimate1847

Downing, T. E. 2012. Views of the frontiers in climate change adaptation economics. Wiley Interdisciplinary Reviews: Climate Change 3(2):161-170. http://dx.doi.org/10.1002/wcc.157

Folke, C. 2006. Resilience: the emergence of a perspective for social-ecological systems analyses. Global Environmental Change 16(3):253-267. http://dx.doi.org/10.1016/j.gloenvcha.2006.04.002

Folke, C., T. Hahn, P. Olsson, and J. Norberg. 2005. Adaptive governance of social-ecological systems. Annual Review of Environment and Resources 30(1):441-473. http://dx.doi. org/10.1146/annurev.energy.30.050504.144511

Geels, F. W. 2011. The multi-level perspective on sustainability transitions: responses to seven criticisms. Environmental Innovation and Societal Transitions 1(1):24-40. http://dx.doi. org/10.1016/j.eist.2011.02.002
Haasnoot, M., J. H. Kwakkel, W. E. Walker, and J. ter Maat. 2013. Dynamic adaptive policy pathways: a method for crafting robust decisions for a deeply uncertain world. Global Environmental Change 23(2):485-498. http://dx.doi.org/10.1016/j.gloenvcha.2012.12.006

Hanger, S., S. Pfenninger, M. Dreyfus, and A. Patt. 2013. Knowledge and information needs of adaptation policy-makers: a European study. Regional Environmental Change 13(1):91-101. http://dx.doi.org/10.1007/s10113-012-0317-2

Hinkel, J., and A. Bisaro. 2014. Methodological choices in solution-oriented adaptation research: a diagnostic framework. Regional Environmental Change, 1-14. http://dx.doi.org/10.1007/ $\underline{\mathrm{s} 10113-014-0682-0}$

Howden, S. M., J.-F. Soussana, F. N. Tubiello, N. Chhetri, M. Dunlop, and H. Meinke. 2007. Adapting agriculture to climate change. Proceedings of the National Academy of Sciences of the United States of America 104(50):19691-19696. http://dx.doi. org/10.1073/pnas.0701890104

International Commission for the Protection of the Rhine (ICPR). 2001. Conference of Rhine ministers 2001. Rhine 2020. Program on the sustainable development of the Rhine. ICPR, Koblenz, Germany.

International Commission for the Protection of the Rhine (ICPR). 2004. Rhine salmon 2020. ICPR, Koblenz, Germany.

International Commission for the Protection of the Rhine (ICPR). 2009. Internationally coordinated management plan for the International River Basin District of the Rhine. ICPR, Koblenz, Germany.

Intergovernmental Panel on Climate Change (IPCC). 2001. Climate change 2001: impacts, adaptation, and vulnerability. Contribution of Working Group II to the Third Assessment Report of the Intergovernmental Panel on Climate Change. Cambridge University Press, Cambridge, UK.

Kabat, P., C. M. J. Jacobs, R. W. A. Hutjes, W. Hazeleger, M. Engelmoer, J. P. M. Witte, R. Roggema, E. J. Lammerts, J. Bessembinder, P. Hoekstra, and M. van den Berg. 2009. Klimaatverandering en het Waddengebied. Position paper klimaat en water [in Dutch]. Wadden Academie, Leeuwarden, Netherlands.

Kwadijk, J. C. J., M. Haasnoot, J. P. M. Mulder, M. M. C. Hoogvliet, A. B. M. Jeuken, R. A. A. van der Krogt, N. G. C. van Oostrom, H. A. Schelfhout, E. H. van Velzen, H. van Waveren, and M. J. M. de Wit. 2010. Using adaptation tipping points to prepare for climate change and sea level rise: a case study in the Netherlands. Wiley Interdisciplinary Reviews: Climate Change 1 (5):729-740. http://dx.doi.org/10.1002/wcc.64

Lavery, S., and B. Donovan. 2005. Flood risk management in the Thames Estuary looking ahead 100 years. Philosophical Transactions of the Royal Society A: Mathematical, Physical and Engineering Sciences 363(1831):1455-1474. http://dx.doi.org/10.1098/ $\underline{\text { rsta.2005.1579 }}$

Lenton, T. M., and J.-C. Ciscar. 2013. Integrating tipping points into climate impact assessments. Climatic Change 117(3):585-597. http://dx.doi.org/10.1007/s10584-012-0572-8 
Moriondo, M., M. Bindi, C. Fagarazzi, R. Ferrise, and G. Trombi. 2011. Framework for high-resolution climate change impact assessment on grapevines at a regional scale. Regional Environmental Change 11(3):553-567. http://dx.doi.org/10.1007/ $\underline{\text { s10113-010-0171-Z }}$

Moriondo, M., G. V. Jones, B. Bois, C. Dibari, R. Ferrise, G. Trombi, and M. Bindi. 2013. Projected shifts of wine regions in response to climate change. Climatic Change 119(3-4):825-839. http://dx.doi.org/10.1007/s10584-013-0739-y

O'Brien, K. L., and J. Wolf. 2010. A values-based approach to vulnerability and adaptation to climate change. Wiley Interdisciplinary Reviews: Climate Change 1(2):232-242.

Oost, A. P., P. Kabat, A. Wiersma, and J. Hofstede. 2009. Climate. Thematic Report No. 4.1. Pages 1-16 in H. Marencic and J. de Vlas, editors. Wadden sea quality status report 2009. Wadden Sea Ecosystem No. 25. Common Wadden Sea Secretariat, Trilateral Monitoring and Assessment Group, Wilhelmshaven, Germany. [online] URL: http://www.waddensea-secretariat.org/sites/default/ files/downloads/qsr-2009.pdf

Oost, A. P., W. Schoorlemmer, P. de Vries, K. de Jong, S. Braaksma, S. E. Werners, R. Hoeksema, Q. Lodder, P. Den Besten, S. Hoekstra, E. Nuijen, E. Schuiling, and E. Reincke. 2010. Basisrapport voor het Plan van Aanpak van het Deltaprogramma Waddengebied. Deltaprogramma Waddengebied, Leeuwarden, Netherlands.

Pyke, C. R., B. G. Bierwagen, J. Furlow, J. Gamble, T. Johnson, S. Julius, and J. West. 2007. A decision inventory approach for improving decision support for climate change impact assessment and adaptation. Environmental Science \& Policy 10(7-8):610-621. http://dx.doi.org/10.1016/j.envsci.2007.05.001

Reeder, T., and N. Ranger. 2011. How do you adapt in an uncertain world? Lessons from the Thames Estuary 2100 project. World Resources Report, Washington, D.C., USA.

Renaud, F. G., J. P. M. Syvitski, Z. Sebesvari, S. E. Werners, H. Kremer, C. Kuenzer, R. Ramesh, A. Jeuken, and J. Friedrich. 2013. Tipping from the Holocene to the Anthropocene: how threatened are major world deltas? Current Opinion in Environmental Sustainability 5(6):644-654. http://dx.doi.org/10.1016/ j.cosust.2013.11.007

Russill, C., and Z. Nyssa. 2009. The tipping point trend in climate change communication. Global Environmental Change 19 (3):336-344. http://dx.doi.org/10.1016/j.gloenvcha.2009.04.001

Stafford Smith, M., L. Horrocks, A. Harvey, and C. Hamilton. 2011. Rethinking adaptation for a $4^{\circ} \mathrm{C}$ world. Philosophical Transactions of the Royal Society A: Mathematical, Physical and Engineering Sciences 369(1934):196-216. http://dx.doi.org/10.1098/ $\underline{\text { rsta.2010.0277 }}$

Steffen, W. 2009. Tipping elements, planetary boundaries and water. Stockholm Waterfront (3-4):10-12.

Stevenson, T. 2005. The Sothebys's wine encyclopedia. Fourth edition. Dorling Kindersley, London, UK.

Todd, C. D., K. D. Friedland, J. C. MacLean, N. Hazon, and A. J. Jensen. 2010. Getting into hot water? Atlantic salmon responses to climate change in freshwater and marine environments. Pages
409-443 in Ø. Aas, S. Einum, A. Klemetsen, and J. Skurdal, editors. Atlantic salmon ecology. Wiley-Blackwell, Oxford, UK. http://dx. doi.org/10.1002/9781444327755.ch16

Trombi, G., M. Bindi, G. Brandani, L. Orioli, A. Stratigea, M. Giaoutzi, K. Georgieva, and K. Borch. 2010. Report on the Tuscany case study, WP6-the Ag2020 Project case studies. European Commission, Contract No. 44280-AG2020. STREP, Brussels, Belgium.

UK Climate Impacts Program (UKCIP). 2010. Identifying adaptation options. UKCIP, Oxford, UK.

United Nations Economic Commission for Europe (UNECE). 2009. Guidance on water and adaptation to climate change. Economic Commission for Europe, Convention on the Protection and Use of Transboundary Watercourses and International Lakes, Geneva, Switzerland. ISBN 978-92-1-117010-8.

van Asselt, M. B. A., and O. Renn. 2011. Risk governance. Journal of Risk Research 14(4):431-449. http://dx.doi.org/10.1080/13669$\underline{877.2011 .553730}$

van Bijsterveldt, M., A. J. Lucas, K. O. Lenferink, L. SchulteUebbing, and W. Zhao. 2012. Adaptation turning point concept to assess nature conservation strategies in the Dutch Wadden Sea Region. Feasibility assessment. Wageningen University, Wageningen, Netherlands.

van Dobben, H. F., and P. A. Slim. 2012. Past and future plant diversity of a coastal wetland driven by soil subsidence and climate change. Climatic Change 110(3-4):597-618. http://dx.doi. org/10.1007/s10584-011-0118-5

van Slobbe, E., S. E. Werners, M. Riquelme-Solara, T. Bölscher, and M. T. H. van Vliet. 2014. The future of the Rhine: stranded ships and no more salmon? Regional Environmental Change 1-11. http://dx.doi.org/0.1007/s10113-014-0683-Z

van Vliet, M. T. H., W. H. P. Franssen, J. R. Yearsley, F. Ludwig, I. Haddeland, D. P. Lettenmaier, and P. Kabat. 2013. Global river discharge and water temperature under climate change. Global Environmental Change 23(2):450-464. http://dx.doi.org/10.1016/ j.gloenvcha.2012.11.002

Vellinga, P., C. A. Katsman, A. Sterl, and J. J. Beersma, editors. 2009. Exploring high-end climate change scenarios for flood protection of the Netherlands. International Scientific Assessment carried out at the request of the Delta Committee. KNMI, De Bilt, Netherlands.

Walker, B. H. 2012. A commentary on "Resilience and water governance: adaptive governance in the Columbia River Basin." Ecology and Society 17(4): 29. http://dx.doi.org/10.5751/ ES-05422-170429

Walker, B. H., N. Abel, J. M. Anderies, and P. Ryan. 2009. Resilience, adaptability, and transformability in the GoulburnBroken Catchment, Australia. Ecology and Society 14(1): 12. [online] URL: http://www.ecologyandsociety.org/voll4/iss1/ art12l

Weisse, R., H. von Storch, H. D. Niemeyer, and H. Knaack. 2012. Changing North Sea storm surge climate: an increasing hazard? Ocean \& Coastal Management 68:58-68. 
Werners, S. E., M. Bindi, T. Bölscher, J. Hinkel, M. Moriondo, A. Oost, A. Patt, S. Pfenninger, E. van Slobbe, and G. Trombi. 2012. Adaptation turning points: identification of impact thresholds, key risk factors and potential adaptive responses. Deliverable D2.3. MEDIATION Project, Wageningen, Netherlands.

Werners, S. E., S. Pfenninger, E. van Slobbe, M. Haasnoot, J. Kwakkel, and R. Swart. 2013. Thresholds, tipping and turning points for sustainability under climate change. Current Opinion in Environmental Sustainability 5(3-4):334-340. http://dx.doi. org/10.1016/j.cosust.2013.06.005

Werners, S. E., J. v. Loon, and A. Oost. 2015. Method selection in adaptation research: the case of the Delta Programme for the Dutch Wadden region. Regional Environmental Change (Special Issue "Approaches to Problem-Oriented Adaptation Research"). In press. http://dx.doi.org/10.1007/s10113-015-0799-9 